V. F. Orobey ${ }^{1}$, DSc, A. F. Dashchenko ${ }^{1}$, DSc, L. V. Kolomiets ${ }^{2}$, DSc, A. M. Limarenko ${ }^{1}$, PhD, R. S. Lobus ${ }^{2}, \mathrm{PhD}$

${ }^{I}$ Odesa National Polytechnic University, c. Odesa

${ }^{2}$ Odesa State Academy of Technical Regulation and Quality, c. Odesa

\title{
ESTIMATION OF CONE-SHAPED BEAMS OF SPECIAL CRANES ON STABILITY
}

The procedure for solution of stability problems of the beams and rod systems, that have change of the cross sizes in various directions, is offered. It is based on the algorithm of numerical and analytical option of the method of boundary elements that was developed in works of one of authors. Several problems of stability of cone-shaped beams are solved, results are characterized by high precision.

Keywords: differential equation with variable coefficients, fundamental system of functions, boundary value problems, MATLAB.

\section{A problem statement}

Problems of stability in Euler statement in case of change of the sizes of a beam and the squeezing force come down to boundary value problems for ordinary differential equations with variable coefficients [10]

$$
\frac{d^{2}}{d x^{2}}\left[E I(x) \frac{d^{2} \vartheta(x)}{d x^{2}}\right]+\frac{d}{d x}\left[N(x) \frac{d \vartheta(x)}{d x}\right]=0
$$

where $E I(x)$ - function of flexural (minimum) rigidity, $\mathrm{kNm}^{2}$;

$$
\vartheta(x) \text { - cross-bending, m; }
$$
section, $k N$.

$$
\text { - function of the squeezing force in beam }
$$

The analytical solution of even of such rather simple equation causes serious mathematical difficulties. In this case, it is necessary to apply numerical methods, for example MKE. At the same time, there are questions on accuracy and reliability of results. Therefore, urgent is a problem of new approaches development for solving this and similar problems.

\section{Analysis of researches and publications}

The solution of boundary value problems with variable coefficients involves researchers to differ- ential equations with the complexity and the wide practical application. Developed in works of the prof. V. Orobey the numerical and analytical option of the method of edge elements (MEE) with success can be applied also to the solution of differential equations with variable coefficients [1-13]. Therefore, in these works, were considered rods with a change of section in only one direction. It is not a typical case. At the same time, in scientific literature mathematical approaches for the accounting of change of the sizes of section in all directions (for example, at a cone) are presented [14-15]. As a result, we will present possibilities of MGE for these cases.

\section{Research purpose}

The purpose of research is application-oriented application of numerical and analytical option of MGE to the decision of problems of stability of the beams in a form of a truncated cone.

Exposition of the main materials of the research

Because it isn't possible analytically to solve the equation (1), it is possible to offer the approximate approach, that makes a problem simple. It is obvious that continuous change of the sizes of cross section and other parameters of a rod can be modelled approximately by step dependence (fig. 1).

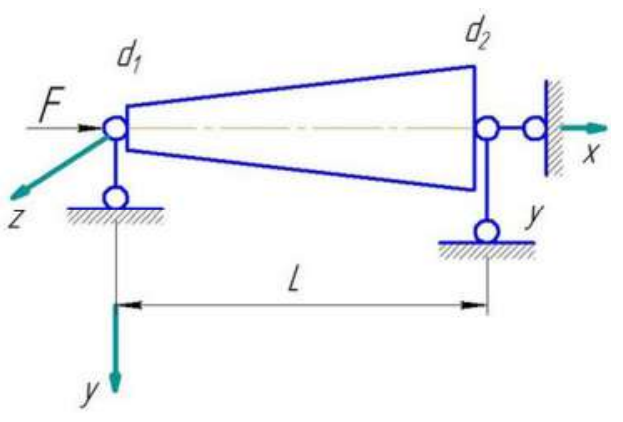

a

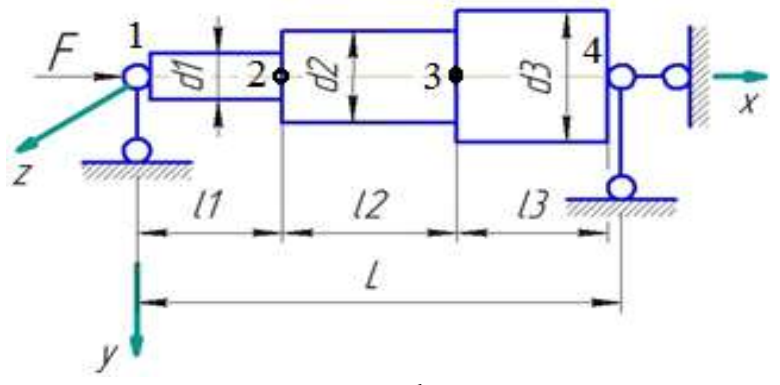

b

Figure 1 - Simulation of a truncated cone step system 
Such change is very convenient because in each beam section change of the sizes of section disappears (and other parameters) and the equations with variable coefficients are automatically given to the equations with constant coefficients which solutions exist and they are unique (Cauchy problems). It is necessary only to use a method which will most effectively cope with a problem of calculation of the sampled system. It is possible to apply methods of initial parameters, movements, final elements, etc. In our opinion, most the numerical and analytical option of a method of boundary elements $[5,8,9,11$, 13] approaches here. The essence of this method comes down to elementary transformations of matrixes of settlement ratios at boundary $x=l_{i}$ value of each element of system according to the scheme

$$
\begin{aligned}
& \mathbf{Y}(l)=\mathbf{A}(l) \cdot \mathbf{X}(0)+\mathbf{B}(l) \rightarrow \mathbf{A}(l) \cdot \mathbf{X}(0)-\mathbf{Y}(l)= \\
& =-\mathbf{B}(l) \rightarrow \mathbf{A}_{*}(l) \cdot \mathbf{X}_{*}(0, l)=-\mathbf{B}(l),
\end{aligned}
$$

where $\mathbf{Y}(l)$ is vector of parameters of a condition of all rods of system in boundary sections $x=l_{i}$, $i=\overline{1, n}$;

$\mathbf{A}(l)$ is quasidiagonal matrix of fundamental functions at $x=l_{i}, i=\overline{1, n}$;

$\mathbf{X}(0)$ is vector of initial parameters of all rods of a system;

$\mathbf{B}(l)$ is external load vector at $x=l_{i}, i=\overline{1, n}$;

$n$-number of elements in a system.

Because of transfer of parameters from $\mathbf{Y}(l)$ in $\mathbf{X}(0)$ the system of the linear algebraic equations turns out. If it is required to solve problems with own values, then $\mathbf{B}(l)=0$ and in case of the tran-

\begin{tabular}{|c|c|c|c|c|}
\hline & 1 & 2 & 3 & 4 \\
\hline 1 & 1 & $A_{12}$ & $-A_{13} / E I_{i}$ & $-A_{14} / E I_{i}$ \\
\hline $\mathbf{A}_{i}=2$ & & $A_{22}$ & $A_{12} / E I_{i}$ & $-A_{13} / E I_{i}$ \\
\hline 3 & & $\begin{array}{c}-A_{32} \cdot E I_{i} \\
A_{32} \cdot E I_{i}\end{array}$ & $A_{22}$ & $A_{12}$ \\
\hline 4 & & & & 1 \\
\hline
\end{tabular}
scendental equation for search of critical forces or frequencies of natural oscillations turns out in the form of determinant

$$
\left|A_{*}\left(l, F_{k p}, \omega\right)\right|=0 \text {. }
$$

Setting an interval for or, it is always possible to find own values [1-13]. The matrix has many remarkable properties:

1. The strong sparseness of a matrix doesn't lead to essential accumulation of errors of rounding from arithmetic operations;

2. It is naturally scaled, it means that her elements smoothly decrease in size on collateral diagonal from left to right. This property causes high stability of numerical operations at the solution of system of the equations (2) or at calculation of determinant;

3. At $\mathrm{x}=0$ it forms a single matrix;

4. She doesn't contain points of a rupture of the 2nd sort in problems of stability and dynamics;

5. It is formed without matrix operations of addition, multiplication and the address. Only quasidiagonalization operation is used.

All these advantages allow to have the simplest logically algorithm of the solution of various boundary problems which differs at the same time in high precision of results. We will present MGE algorithm on examples of the problems of stability of the truncated cone considered in works $[14,15]$.

The stability equation for the sampled scheme according to fig. $1, \mathrm{~b}$ and $\mathrm{i}$-section will take a form:

$$
E I_{i} \frac{d^{4} \vartheta(x)}{d x^{4}}+F \frac{d^{2} \vartheta(x)}{d x^{2}}=0
$$

The matrix of fundamental orthonormalized functions for this equation is known and has a following form:

where

$$
\begin{aligned}
& A_{12}=\frac{\sin \left(t_{i} x\right)}{t_{i}} ; A_{13}=\frac{1-\cos \left(t_{i} x\right)}{t_{i}^{2}} ; A_{14}=\frac{t_{i} x-\sin \left(t_{i} x\right)}{t_{i}^{3}} ; \\
& A_{22}=\cos \left(t_{i} x\right) ; A_{32}=-t_{i} x \cdot \sin \left(t_{i} x\right) ; t_{i}=\sqrt{F / E I_{i}} .
\end{aligned}
$$

Parameters of rigidity are entered into $\mathbf{A}_{i}$ matrix for simpler performance of conditions of joining of sections in internal points of a beam. It is the simplest way to calculate values in the middle of each site. Cone section, a circumference, and diameter changes due to the following rule (fig. 1, a):

$$
d(x)=d_{1}\left(a-b x^{k}\right),
$$


Matrix

$F$ ) of the equation (3) is formed as follows. Let $n=3$ (fig. 1, b). Matrixes of initial and final parameters of the sampled beam are formed. In them we consider regional conditions of bearing and a condition of a continuity of parameters of a bend in internal points.

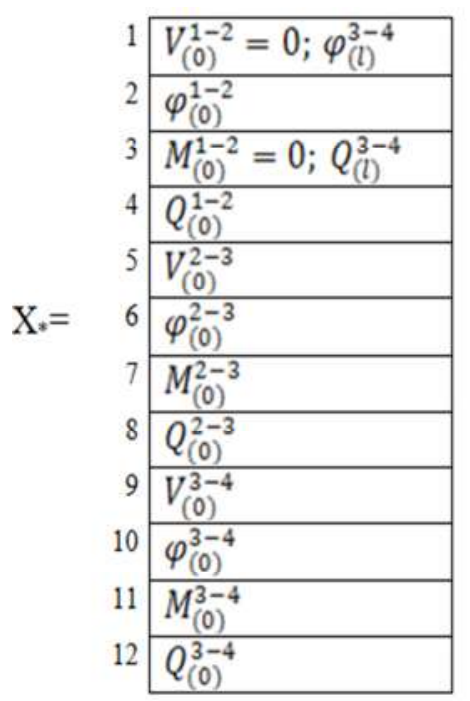

$$
\mathrm{Y}=\begin{array}{r|l|}
\hline 1 & V_{(l)}^{1-2}=V_{(0)}^{2-3} \\
\hline 2 & \varphi_{(l)}^{1-2}=\varphi_{(0)}^{2-3} \\
\hline 3 & M_{(l)}^{1-2}=M_{(0)}^{2-3} \\
\hline 4 & Q_{(l)}^{1-2}=Q_{(0)}^{2-3} \\
\hline 5 & V_{(l)}^{2-3}=V_{(0)}^{3-4} \\
\hline 6 & \varphi_{(l)}^{2-3}=\varphi_{(0)}^{3-4} \\
\hline 7 & M_{(l)}^{2-3}=M_{(0)}^{3-4} \\
\hline 8 & Q_{(l)}^{2-3}=Q_{(0)}^{3-4} \\
\hline 9 & V_{(l)}^{3-4}=0 \\
\hline 10 & \varphi_{(l)}^{3-4} \\
\hline 11 & M_{(l)}^{3-4}=0 \\
\hline 12 & Q_{(l)}^{3-4} \\
\hline
\end{array}
$$

Follows from a matrix $\mathbf{X}_{*}$ that in a matrix $\mathbf{A}_{*}$ it is necessary to nullify the 1 and 3 columns. We transfer independent parameters of a $\mathbf{Y}$ matrix to the place of zero parameters of a $\mathbf{X}$ matrix. Dependent parameters of a $\mathbf{Y}$ matrix transfer on the equations of their communication. As a result, the matrix is supplemented with the compensating elements. The

\begin{tabular}{|c|c|c|c|c|c|c|c|c|c|c|c|c|}
\hline & 1 & 2 & 3 & 4 & 5 & 6 & 7 & 8 & 9 & 10 & 11 & 12 \\
\hline 1 & & $\mathrm{~A}_{12}$ & & $-\mathrm{A}_{14} / \mathrm{EI}_{1}$ & -1 & & & & & & & \\
\hline 2 & & $\mathrm{~A}_{22}$ & & $-\mathrm{A}_{13} / \mathrm{EI}_{1}$ & & -1 & & & & & & \\
\hline 3 & & $-\mathrm{A}_{32} \mathrm{EI}_{1}$ & & $\mathrm{~A}_{12}$ & & & -1 & & & & & \\
\hline 4 & & & & 1 & & & & -1 & & & & \\
\hline 5 & & & & & $\bar{~} 1$ & $\overline{A_{12}}$ & $-\mathrm{A}_{12} / \mathrm{EI}_{2}$ & $-\mathrm{A}_{14} / \mathrm{EI}_{2}$ & -1 & & & \\
\hline 6 & & & & & & $\mathrm{~A}_{22}$ & $-\mathrm{A}_{12} / \mathrm{EI}_{2}$ & $-\mathrm{A}_{13} / \mathrm{EI}_{2}$ & & -1 & & \\
\hline $\mathrm{A}_{*}=$ & & & & & & $-\mathrm{A}_{32} \mathrm{EI}_{2}$ & $\mathrm{~A}_{22}$ & $\mathrm{~A}_{22}$ & & & -1 & \\
\hline 8 & & & & & & & & 1 & & & & -1 \\
\hline 9 & & & & & & & & & 1 & $\overline{A_{12}}$ & $-\mathrm{A}_{13} / \mathrm{EI}_{3}$ & $-\mathrm{A}_{14} / \mathrm{EI}_{3}$ \\
\hline 10. & -1 & & & & & & & & & $\mathrm{~A}_{22}$ & $-\mathrm{A}_{12} / \mathrm{EI}_{3}$ & $-\mathrm{A}_{13} / \mathrm{EI}_{3}$ \\
\hline 11 & & & & & & & & & & $-\mathrm{A}_{32} \mathrm{EI}_{3}$ & $\mathrm{~A}_{22}$ & $\mathrm{~A}_{12}$ \\
\hline 12 & & & -1 & & & & & & & & & 1 \\
\hline
\end{tabular}
matrix of stability of a beam has a following form:
Matrixes of the equation (3) for beams with other conditions of bearing are similarly formed. From the equation (3) it is possible to determine by method of search critical forces which are provided in a such way:

$$
-\longrightarrow \text {, }
$$

where $\lambda$-dimensionless parameter of critical force;

$\mu$ - coefficient of the specified length.

Between $\lambda$ and $\mu$ there is a dependence.

$$
\lambda \mu=\pi
$$

Practice of the solving of problems with variable coefficients shows that results turn out almost exact already in case of number of sections of $n \geq 30$ [1-13]. For tasks of operations [14, 15] the matrix was created automatically according to the program in MATLAB cutoff in case of $n=50$. In table 1 parameters $\lambda$ for the first three critical forces of different cone-shaped beams are provided in case of $a=1 ; b=0,01 ; k=1 ; L=1$. 
Table 1 - Three first parameters of critical forces

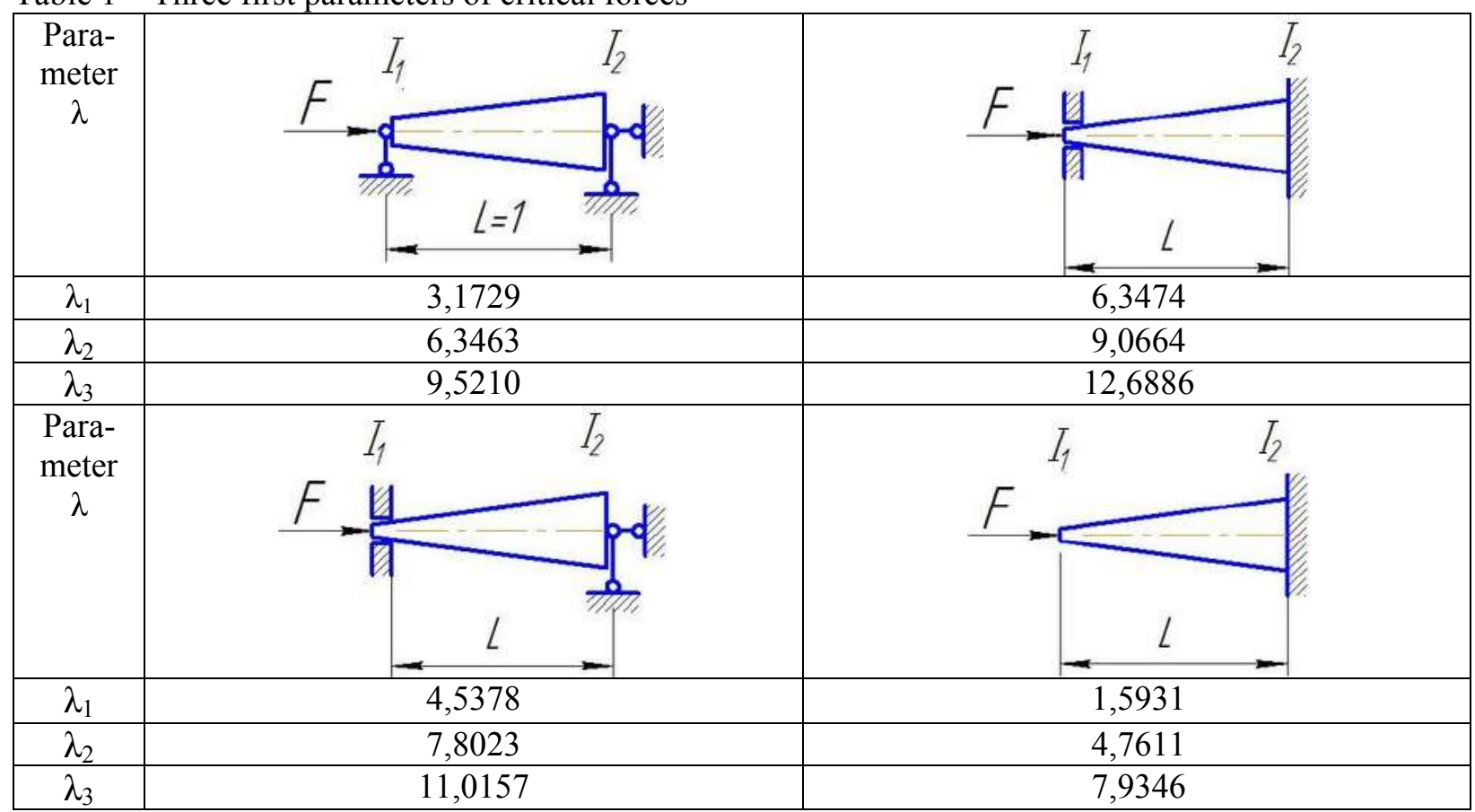

Data from table 1 can be compared to results of works $[14,15]$. Application of function of Green has allowed to receive exact result for $\lambda 1$ at a hinged bearing [14]

$$
\lambda_{1}=3,17 .
$$

It can be seen that results of MGE and work [14] coincide. In work [15] by means of the integrat- ed equations we have received approximate value $\lambda_{1}=3,11$. This result differs a little from exact, but it is doubtful. Value $\lambda_{1}$ for a cone-shaped beam should be more than $\pi$. Values of parameter $\lambda_{1}$ depending on the relation of diameters of cone-shaped beams are presented in table 2 where $a=1 ; L=1 ; k=1$.

Table 2 - Parameters $\lambda 1$ at change of the relations of sections diameters

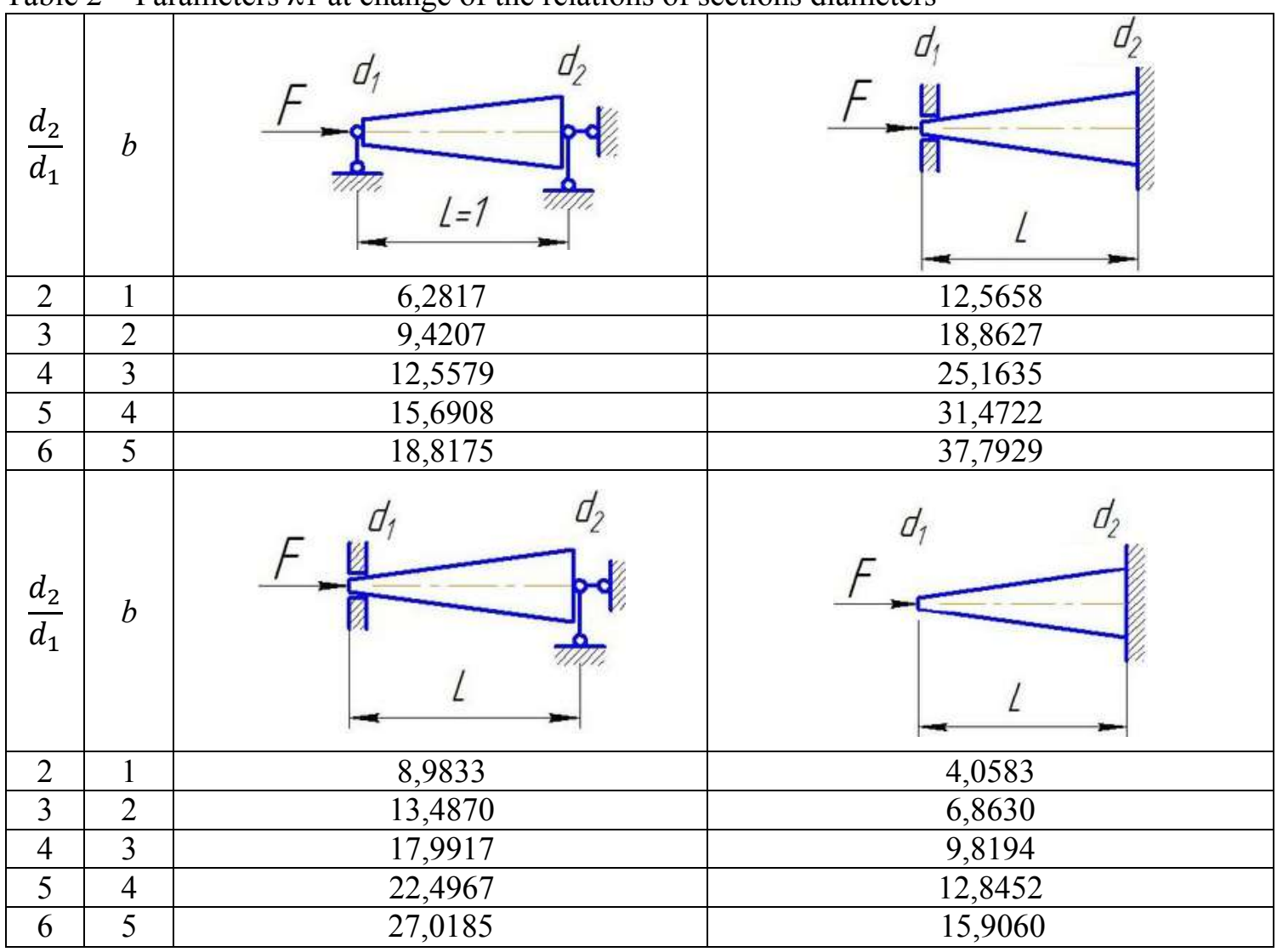


It follows from table 2 that at smooth change of the cross sizes of a rod it is possible to increase significantly critical forces of such constructions as columns, chimneys, various support, TV and radio towers, towers.

\section{Conclusions}

The analysis of the provided material shows that the calculation procedure on stability of beams with distributed parameters, based on MGE, allows effectively, precisely and authentically to solve the complex problems which don't have the analytical decision. In particular, for cone-shaped (as well the piramideshape) beams it isn't necessary to create quite bulky function of Green [14] or to solve integrable equations [15]. In MGE it is enough to use the only system of fundamental orthonormalized functions of the appropriate differential equation with constant coefficients. Additional benefit is the minimum requirements to variable coefficients of a differential equation. They can have ruptures of the 1st kind, a point of a fracture and arbitrary set of the continuous functions [1-13] that significantly expands a circle of solvable problems not only theory of stability, but also other sciences.

\section{References}

1. Оробей В. Ф. Численно-аналитическое решение краевых задач для систем обыкновенных дифференциальных уравнений с переменными коэффициентами / В. Ф. Оробей, Г. В. Кострова. - Труды Одесск. политехн. ун-та. - Одесca, 2007. - Вып. 1(27). - С. 23 - 30.

2. Оробей В.Ф. Решение задачи устойчивости плоской формы изгиба тонкостенных стержневых систем методом граничных элементов / В. Ф. Оробей, Г. В. Кострова. - Труды Одесск. политехн. ун-та. - Одесса, 2007. - Вып. 2(28). C. $8-24$.

3. Оробей В. Ф. Метод граничных элементов в задачах устойчивости арок / В. Ф. Оробей, Г. В. Кострова, В. Н. Пурич // Труды Одесск. политехн. ун-та. - Одесса, 2009. - Вып. 1(31). C. $7-14$.

4. Оробей В. Ф. Расчет статически неопределимых балок с распределенными параметрами / В. Ф. Оробей, И. Б. Корнеева, Д. О. Бондаренко. - Вісник Одеської державної академії будівництва та архітектури. - Одеса, 2009. Вип. 36. - С. $322-328$.

5. Дащенко А. Ф. Численно-аналитический метод граничных элементов / А. Ф. Дащенко, Л.В.Коломиец, В. Ф. Оробей, Н. Г. Сурьянинов. - Одесса: ВМВ, 2010. - Т. 1. - 415 с. - Т. 2. $510 \mathrm{c.}$
6. Оробей В. Ф. Устойчивость плоской формы изгиба тонкостенных стержневых систем / В. Ф. Оробей, А. Ф. Чумак // Прикладная механика. - 2009. - Т. 45. - № 5. - С. $110-123$.

7. Оробей В. Ф. Колебания балок с переменной жесткостью / B. Ф. Оробей, К. С. Тыманюк. - Труды Одесск. политехн. унта. - Одесса, 2010. - Вып. 1(33) - 2(34). C. $16-22$.

8. Дащенко А. Ф. MATLAB в механике деформируемого твердого тела / А.Ф. Дащенко, В. Ф. Оробей, Н. Г. Сурьянинов. - Харьков: «Бурун книга», 2011. - $480 \mathrm{c.}$

9. Оробей В. Ф. Практикум по методам решение краевых задач / В. Ф. Оробей, Н. Г. Сурьянинов. - Одесса: Астропринт, 2011. $408 \mathrm{c}$

10. Оробей В. Ф. Устойчивость балок с распределенными параметрами / В. Ф. Оробей, Г. В. Кострова. - Праці Одеськ. політехн. ун-ту. - Одеса, 2011. - С. 15 - 23.

11. Дорофеев В. С. Новые методы расчета систем с дискретно-непрерывным распределением параметров / В. С. Дорофеев, А. В. Ковров, Ю. С. Крутий, В. Ф. Оробей, Н. Г. Сурьянинов, Р. М. Таций, Т. И. Ушак. - Одесса: Эвен, 2012. $378 \mathrm{c}$.

12. Оробей В. Ф. Метод граничных элементов в задачах устойчивости плоской формы изгиба балок прямоугольного сечения / В. Ф. Оробей, А. Ф. Дащенко, А. М. Лимаренко. - Збірник наукових праць Одеської державної академіі технічного регулювання та якості. - Одеса, 2015. - № 2(7). - С. 47 - 54.

13. Оробей В. Ф. Метод граничных элементов в задачах расчета машиностроительных конструкций / В. Ф. Оробей, А. Анискин, А. Ф. Дащенко, Л. В. Коломиец, А. М. Лимаренко, Б. Солдо. - Одесса: «Апрель», 2016. - 761 с.

14. Богачева В. Е. Функция Грина и задача на собственные значения / В. Е. Богачева, И. Н. Беляева, Н. А. Чеканова, Б. М. Башкатов, Н. Н. Чеканова, И. С. Кузнецова. - Вісник Херсонського нац. технічн. ун-ту. - Херсон, 2016. №3(58). - C. $15-19$.

15. Михлин С. Г. Приложение интегральных уравнений к некоторым проблемам механики, математической физики и техники / С. Г. Михлин. - М. - Л.: ОГИЗ техн.-теор. лит., 1947. $-304 \mathrm{c}$.

\section{Надійшла до редакиії 12.06.2017}

Рецензент: д.т.н., проф. Усов А. В., Одеський національний політехнічний університет, м. Одеса. 
В. Ф. Оробей, д.т.н., А. Ф. Дащенко, д.т.н., Л. В. Коломиец, д.т.н., А. М. Лимаренко, к.т.Н., Р. С. Лобус, к.т.н.

\section{РАСЧЕТ КОНУСООБРАЗНЫХ БАЛОК СПЕЦИАЛЬНЫХ КРАНОВ НА УСТОЙЧИВОСТЬ}

Предложена проиедура решения задач устойчивости балок и стержневых систем, имеющих изменение поперечных размеров в различных направлениях. В основе предлагаемого подхода лежит алгоритм численно-аналитического варианта метода граничных элементов, разработанного в трудах одного из авторов. Решен ряд задач устойчивости конусообразных балок, результаты характеризуются высокой точностью.

Ключевые слова: дифференциальные уравнения с переменными коэффициентами, фундаментальная система функиий, краевые задачи на собственные значения, MATLAB.

В. Ф. Оробей, д.т.н., О. Ф. Дащенко, д.т.н., Л. В. Коломієць, д.т.н., О. М. Лимаренко, к.т.н. Р. С. Лобус, к.т.н.

\section{РОЗРАХУНОК КОНУСОПОДІБНИХ БАЛОК СПЕЦІАЛЬНИХ КРАНІВ НА СТІЙКІСТЬ}

Запропоновано процедуру розв'язання задач стійкості балок і стрижневих систем, що мають зміну поперечних розмірів в різних напрямках. В основі запропонованого підходу лежить алгоритм чисельно-аналітичного варіанту методу граничних елементів, розробленого в прачях одного з авторів. Вирішено ряд завдань стійкості конусоподібних балок, результати характеризуються високою точністю.

Ключові слова: диференціальні рівняння зі змінними коефіцієнтами, фундаментальна система функцій, крайові задачі на власні значення, MATLAB.

УДК 621.317 .1

О. М. Величко, д.т.н., В. В. Ісаєв

Державне підприємство «Всеукраїнський державний науково-виробничий центр стандартизачії, метрології, сертифікачії та захисту прав споживачів», м. Київ

\section{ДЕЯКІ ОСОБЛИВОСТІ КАЛІБРУВАННЯ БАГАТОФУНКЦІОНАЛЬНИХ КАЛІБРАТОРІВ ЗМІННОГО СТРУМУ}

У статті запропоновано методику калібрування міри показників якості електричної енергії для визначення поправки відтворюваного кута між двома фазними напругами. В основі методики лежить метод опосередкованого вимірювання кута зсуву фаз із застосуванням прецизійного вольтметру змінної напруги. Проаналізовано внесок складових вхідних величин та запропоновано бюджет невизначеності вимірювань. Представлено результати, отримані при калібруванні багатофункиіонального калібратора змінного струму, за пропонованою методикою та оцінено внесок попарної корелячії вимірюваних фазних та міжфазної напруг у розширену невизначеність.

Ключові слова: змінна напруга, прецизійний вольтметр, кут зсуву фаз, невизначеність вимірювання.

\section{Вступ}

Важливою складовою народного господарства будь-якої промислово розвиненої держави $\epsilon$ енергетичний сектор. Неможливо уявити функціонування сучасних великих технологічних комплексів виробництва, сільського господарства, навіть, невеликої офісної фірми без енергетичного забезпечення, зокрема, електричного живлення. Безліч електричних пристроїв та приладів потребують підведення до них якісної електричної енергії мережею однофазного чи багатофазного виконання. Від забезпечення певних параметрів електроенергії залежить, наскільки точно виконуватимуть свої функції електричні пристрої та прилади, а також, чи відповідатиме тривалість функціонування цих засобів гарантованому виробником терміну експлуатації. Національний стандарт ДСТУ ЕN 15160 [1], гармонізований із європейськими вимогами, встановлює перелік показників якості 